\title{
Properties of artificial aggregates of coal bottom ash-dredged soil system added with waste glass
}

\author{
Sinae Jo and Seunggu Kang ${ }^{\dagger}$ \\ Department of Advanced Materials Engineering, Kyonggi University, Suwon 443-760, Korea
}

(Received March 21, 2013)

(Revised May 21, 2013)

(Accepted May 24, 2013)

\begin{abstract}
In this study, the effect of addition of waste glassy slag produced from recycling of spent catalyst (denoted as waste glass hereafter) on the physical properties of artificial aggregates made of coal bottom ash and dredged soil ( $7: 3$ by weight base) was evaluated. Especially, the bloating behavior of artificial aggregates was analyzed by performing the relation study between the apparent density, water absorption and microstructure. The apparent density of artificial aggregates increased slightly with sintering temperature at $1050 \sim 1150^{\circ} \mathrm{C}$, but decreased above $1150^{\circ} \mathrm{C}$ showing bloating phenomenon. The bloating behavior of artificial aggregates was decreased so the apparent density increased with amount of waste glass added. Also, the water absorption of artificial aggregates decreased with sintering temperature. Above $1200^{\circ} \mathrm{C}$, big fissure and much liquid were formed at the surface of artificial aggregates and these phenomena could be suppressed by increasing amount of waste glass added. The artificial aggregates fabricated in this study had an apparent density of $1.1 \sim 1.6$ and water absorption of $8 \sim 22 \%$ which meet KS requirements for the artificial lightweight aggregates.
\end{abstract}

Key words Artificial aggregates, Coal bottom ash, Dredged soil, Waste glass, Spent catalyst

\section{폐유리가 첨가된 석탄바닥재-준설토 계 인공골재의 특성}

\author{
조시내, 강승구 \\ 경기대학교 신소재공학과, 수원 443-760 \\ (2013년 3월 21일 접수) \\ (2013년 5월 21일 심사완료) \\ (2013년 5월 24일 게재확정)
}

요 약 본 연구에서는 석탄 바닥재와 준설토( $7: 3$, 무게비율)로 제조된 인공골재의 물성에 미치는 폐촉매 유리질 슬래 그(이하 폐유리로 칭함) 첨가 영향을 평가하였다. 특히 인공골재의 비중 및 흡수율 결과를 미세구조와 연계하여 그 발포특 성을 고찰하였다. $1050 \sim 1150^{\circ} \mathrm{C}$ 범위 내에서 인공골재 비중은 소성온도와 함께 약간 증가되었으나 그 이상의 소성온도에서 는 감소하여 발포경향을 나타내었다. 폐유리 첨가량이 증가할수록 인공골재의 발포특성은 억제되었으며, 비중은 증가하는 경향을 보였다. 한편 인공골재 흡수율은 소성온도의 증가와 함께 감소하였다. $1200^{\circ} \mathrm{C}$ 이상의 소성온도에서 표면에 균열이 발생함과 동시에 다량의 액상이 형성되었으나, 이러한 현상들은 폐유리를 첨가함으로서 제어할 수 있었다. 본 연구에서 제 조된 인공골재의 비중은 1.1 1.6, 흡수율은 8 22\% 범위값을 나타내어 인공경량골재의 $\mathrm{KS}$ 기준을 만족하였다.

\section{1. 서 론}

산업발전에 따라 백금족 폐촉매의 양이 증가되고 있어, 이로부터 고가인 백금족 금속의 회수 요구가 증대하고 있다. 국내에서 발생하는 폐촉매로는 정유공장에서 발생

\footnotetext{
Corresponding author

Tel: +82-31-249-9767

Fax: +82-31-249-9774

E-mail: sgkang@kgu.ac.kr
}

하는 석유 화학 폐촉매와 자동차 배기가스 정화용 폐촉 매 등이 있으며, 이중 석유화학 촉매의 수명은 대략 3 4 년 주기로 일부분씩 교체 하고 있다. 폐촉매에서 백금을 회수하는 가장 일반적인 방법은 폐촉매를 용제와 함께 용융시켜 슬래그를 얻는 과정에서 백금을 농축 분리시키 는 건식법이다[1]. 그러나 건식법에 의한 백금족 금속 회수는 다량의 중금속을 함유하고 있는 유리질의 폐 슬 래그를 배출하게 되므로 환경오염의 문제를 일으킨다[2]. 한편, 석탄바닥재는 석탄이 발전소 보일러 내에서 연 
소될 때 괴상 또는 입경이 큰 재 성분이 하부로 낙하된 것이다. 이는 비산재와 달리 균일하지 못한 형상 및 조 성 등으로 인하여 재활용에 한계가 있어 거의 매립 처리 를 하고 있는 실정이다[3-7]. 또한 준설작업 시 발생되는 준설토는 연간 4,600만 톤에 달하고 있으나, 대부분 매 립 및 해양 투기에 의해 처리되고 있어 이에 대한 안정 화 및 재활용 연구가 시급하다[8-10].

본 논문에서는 석탄 바닥재, 준설토 그리고 폐촉매 유 리질 슬래그(이하 폐유리로 칭함)를 재활용하기 위하여 이들을 다양한 비율로 혼합하여 인공골재를 제조하였다. 또한 제조된 골재의 물리적 특성과 발포경향을 미세구조 관찰결과와 연계하여 고찰하였으며, 특히 폐유리가 인공 골재의 물성에 미치는 영향을 분석하였다.

\section{2. 실험방법}

본 실험에서 사용한 원료로는 국내 $\mathrm{Y}$ 화력발전소에서 배출된 석탄바닥재(coal bottom ash)와 동일한 발전소에 서 배출된 준설토(dredged soil), 국내 $\mathrm{H}$ 사에서 배출된 폐촉매 유리질 슬래그(이하 폐유리로 칭함)를 사용하였 다. 각 원료의 화학적 성분을 XRF(ZSX-100e, Rigaku, Japan)로 분석하여 Table 1에 나타내었다.

본 연구에서 제조된 인공골재에 대한 각 원료의 배합 비를 Table 2에 나타내었다. 석탄바닥재를 준설토와 $7: 3$ 의 무게비율로 혼합한 후 폐유리를 $0 \sim 15 \mathrm{wt} \%$ 로 첨가하 여 인공골재를 제조하였다. 시편명에서 $\mathrm{W}$ 는 폐유리를 의미하며, 숫자는 폐유리 첨가량 $(\mathrm{wt} \%)$ 을 나타낸다.

모든 원료들은 $110^{\circ} \mathrm{C}$ 에서 $24 \mathrm{hr}$ 건조한 후, 핀밀(pin $\mathrm{mil}$ )을 이용하여 $150 \mu \mathrm{m}$ 이하의 크기로 분쇄하여 사용 하였다. 각 원료가 혼합된 배치분말을 볼밀을 이용하여 24시간 혼합하고, $20 \mathrm{wt} \%$ 물을 첨가하여 직경 $9 \sim 11 \mathrm{~mm}$ 의 구형 시편으로 성형한 뒤, 이를 $1050 \sim 1250^{\circ} \mathrm{C}$ 에서 10 분간 직화소성(flash sintering)하여 인공골재를 제조하 였다. 직화소성법은 미리 예열시킨 로(furnace)에 성형체 를 넣어 일정시간 소성한 뒤 바로 상온으로 배출시키는 방식이다. 사용된 원료의 화학조성은 $\mathrm{XRF}$ 를 사용하여
Table 2

Batch composition of artificial aggregates (wt $\%)$

\begin{tabular}{llll}
\hline Specimen I.D. & $\begin{array}{l}\text { Row materials } \\
\text { ash }\end{array}$ & $\begin{array}{l}\text { Dredged } \\
\text { soil }\end{array}$ & $\begin{array}{l}\text { Amount of waste } \\
\text { glass added }\end{array}$ \\
\hline $0 \mathrm{~W}$ & & & 0 \\
$5 \mathrm{~W}$ & 7 & 3 & 5 \\
$10 \mathrm{~W}$ & & & 10 \\
$15 \mathrm{~W}$ & & 15 \\
\hline
\end{tabular}

분석하였고, 제조된 인공경량골재의 비중 및 흡수율은 KS F 2503 “굵은 골재의 비중 및 흡수율 시험 방법”을 사용하여 측정하였으며, 소성체 절단면의 미세구조는 광 학현미경(DCS-105, Sometech-vision, Korea)을 이용하 여 관찰하였다.

\section{3. 결과 및 고찰}

본 연구에서 사용된 원료들의 발포 가능성을 예측하기 위하여 조성 산화물들을 전통적인 세라믹 3축 성분계에 의거하여 분류하였다. 즉, $\mathrm{RO}_{2}(\mathrm{R}=$ metals $)$ 형태의 구조 산화물(frame oxides), $\mathrm{RO}$ 및 $\mathrm{R}_{2} \mathrm{O}$ 형태의 융제 산화물 (fluxing oxides) 그리고 $\mathrm{R}_{2} \mathrm{O}_{3}$ 형태의 중성 산화물(neutral oxides)로 분류하고 이를 Fig. 1의 세라믹 3축 성분계 도표에 나타내었다. 여기서 '구조산화물 + 중성산화물 + 융제산화물 $=100 '$ 으로 하였고 기타 산화물, 탄소 그리고 강열감량 성분들은 제외하였다.

Fig. 1에 점선으로 표시된 영역은 Riley가 발포에 효 과적인 조성이라고 보고한 것이다[11]. Riley는 다공성 세라믹스를 제조할 때 가장 중요한 인자는 열처리 온도 와 화학조성이며, 원료가 가열됨에 따라 생성되는 액상 이 적당한 점성에 도달하였을 때 가스도 함께 발생되어 야만 시편이 발포된다고 하였다[11]. Fig. 1에 보였듯이, 본 연구에 사용된 준설토 $(\bigcirc)$ 는 Riley의 발포영역에 포 함되어있지만, 석탄바닥재 $(\mathbf{O})$ 는 약간 벗어나 있다. 또한 폐유리(ם)는 $\mathrm{SiO}_{2}$ 의 양이 적어 발포영역에서 완전히 벗어나 있다.

Table 1

Chemical compositions of raw materials (wt \%)

\begin{tabular}{|c|c|c|c|c|c|c|c|c|c|c|c|c|c|}
\hline \multirow{2}{*}{$\begin{array}{l}\text { Components } \\
\text { Raw } \\
\text { materials }\end{array}$} & \multirow{2}{*}{$\begin{array}{l}\begin{array}{l}\text { Frame } \\
\text { oxide }\end{array} \\
\mathrm{SiO}_{2}\end{array}$} & \multicolumn{2}{|c|}{ Neutral oxides } & \multicolumn{5}{|c|}{ Fluxing oxides } & \multicolumn{5}{|c|}{ Others } \\
\hline & & $\mathrm{Al}_{2} \mathrm{O}_{3}$ & $\mathrm{Fe}_{2} \mathrm{O}_{3}$ & $\mathrm{CaO}$ & $\mathrm{MgO}$ & $\mathrm{Na}_{2} \mathrm{O}$ & $\mathrm{K}_{2} \mathrm{O}$ & $\mathrm{MnO}$ & $\mathrm{TiO}_{2}$ & $\mathrm{P}_{2} \mathrm{O}_{5}$ & $\mathrm{C}$ & Ig. loss & Total \\
\hline Bottom ash & 60.9 & 25.5 & 4.1 & 1.0 & 0.9 & 0.1 & 3.2 & 0.0 & 0.8 & 0.8 & 1.7 & 1.0 & 100 \\
\hline Dredged soil & 70.7 & 14.4 & 3.8 & 0.8 & 0.2 & 2.5 & 2.7 & 0.0 & 0.8 & 0.0 & 0.0 & 4.1 & 100 \\
\hline *Waste glass & 30.3 & 36.5 & 0.7 & 23.1 & 7.9 & 0.2 & 0.3 & 0.0 & 0.4 & 0.5 & 0.0 & 0.0 & 100 \\
\hline
\end{tabular}

*Waste glass indicates the waste glassy slag produced from recycling of spent catalyst. 


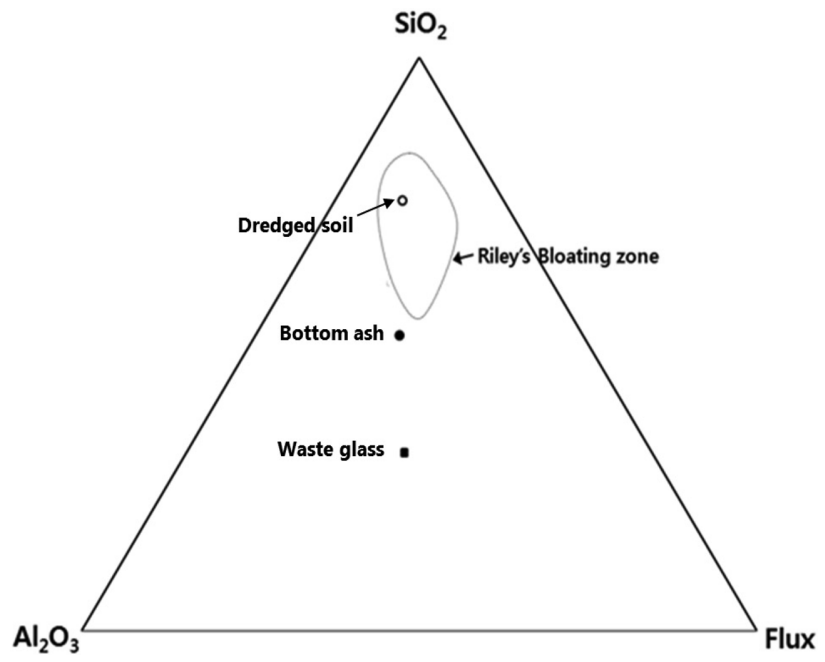

Fig. 1. Ternary diagram of ceramic composition showing the bloating zones during sintering process presented by Riley [11]. The specimens fabricated in this study are included in the Riley's bloating zone (O: bottom ash, $\bigcirc$ : dredged soil, waste glass).

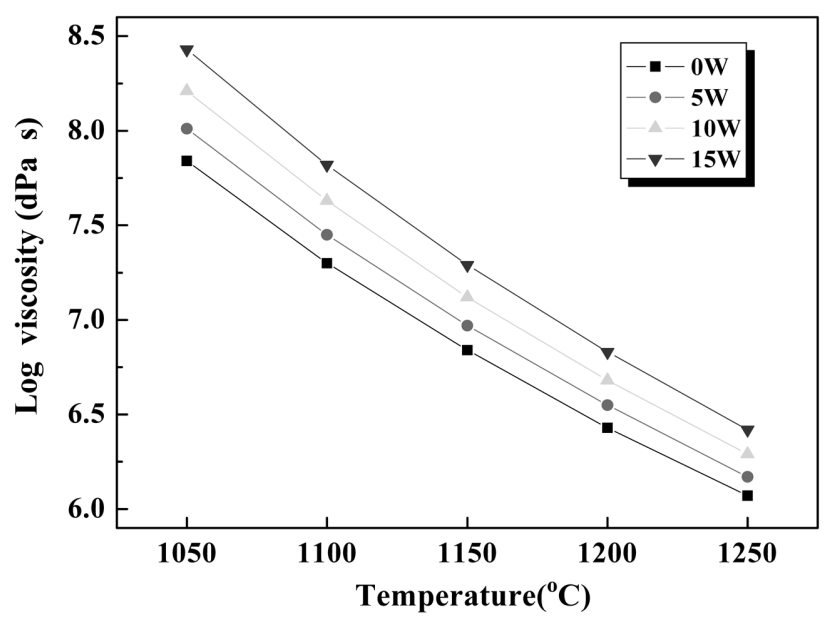

Fig. 2. Log viscosity of the mixture of coal bottom ash and dredged soil ( $7: 3$ by weight base) as a function of temperature and waste glass content added.

Fig. 2에 폐유리의 첨가량과 온도변화에 따른 시편혼 합물의 점도를 계산하였다. 유리 액상의 점도 $(\eta)$ 는 온도 $\mathrm{T}$ 에서 Lakatos가 제안한 다음 실험식(1)을 사용하되, 시 편혼합물은 모두 단일 산화물로 구성되었다고 가정하였 다[12, 13].

$$
\log \eta=-\mathrm{A}+\mathrm{B} /\left(\mathrm{T}-\mathrm{T}_{0}\right)
$$

여기서 $\mathrm{A}, \mathrm{B}$, 그리고 $\mathrm{T}_{0}$ 는 성분변화에 따라 실험적으 로 얻어진 상수이다. Fig. 2에 보였듯이, 융액의 점도는 온도증가에 따라 낮아지는 경향을 나타내었다. 한편, 같 은 온도에서 시편 내 폐유리 함유량이 높을수록 융액의 점도는 증가하였는데 이는 폐유리의 높은 알루미나 함량 $(36.5 \mathrm{wt} \%)$ 에 기인한다. 일반적으로 유리의 고온점도는

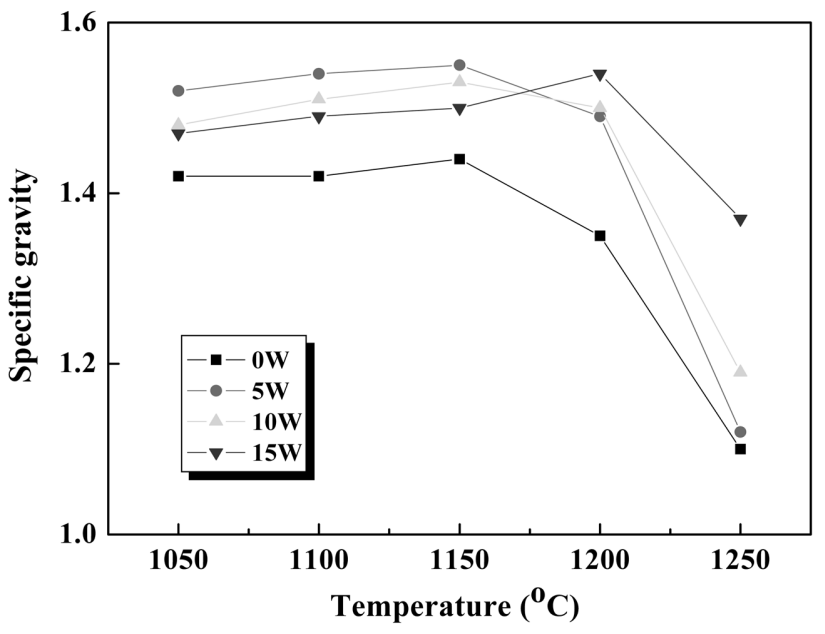

Fig. 3. Specific gravity of artificial aggregates sintered at 1050 $1250^{\circ} \mathrm{C}$ for $10 \mathrm{~min}$ using flash sintering method in electric furnace.

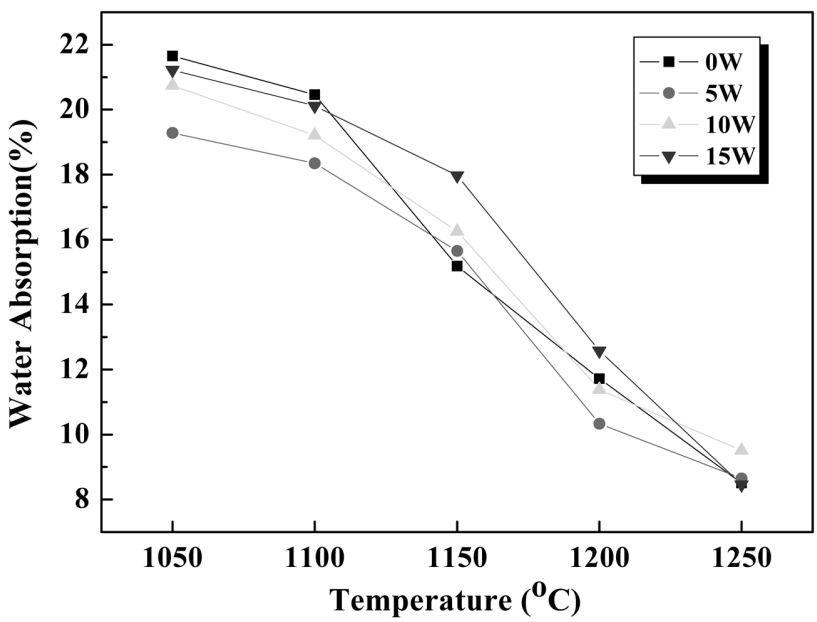

Fig. 4. Water absorption of artificial aggregates sintered at 1050 $1250^{\circ} \mathrm{C}$ for $10 \mathrm{~min}$ using flash sintering method in electric furnace.

알루미나 함량이 높을수록 함께 증가한다[14]. 인공경량 골재의 소결 시 골재표면을 감싸주는 적절한 점성의 액 상은 내부 가스가 방출되는 것을 억제함으로서 시편의 발포현상을 촉진시킨다. 따라서 시편 내 폐유리 함유량 이 높을수록 발포현상이 억제될 것으로 예측된다.

$1050 \sim 1250^{\circ} \mathrm{C}$ 의 온도범위에서의 직화소성된 인공골재의 비중 값을 Fig. 3에 나타내었다. 모든 시편들은 1050 $1150^{\circ} \mathrm{C}$ 의 저온 범위에서 소성온도 증가와 함께 비중이 약간 증가하여 전형적인 치밀화 소결거동을 나타내었다. $1200^{\circ} \mathrm{C}$ 에서 $15 \mathrm{~W}$ 시편을 제외하고는 발포현상이 시작 되어, 비중이 감소하기 시작했으며, $1250^{\circ} \mathrm{C}$ 에서 모든 시 편이 발포거동을 보였다.

발포현상이 완전히 일어난 $1250^{\circ} \mathrm{C}$ 에서 소결된 경우, 폐유리 함량과 함께 인공골재의 비중값이 증가하였다. 즉, 발포경향이 폐유리 함량에 반비례하는 관계를 보였 다. 이는 $1250^{\circ} \mathrm{C}$ 에서 생성된 액상의 점도가 폐유리 함 


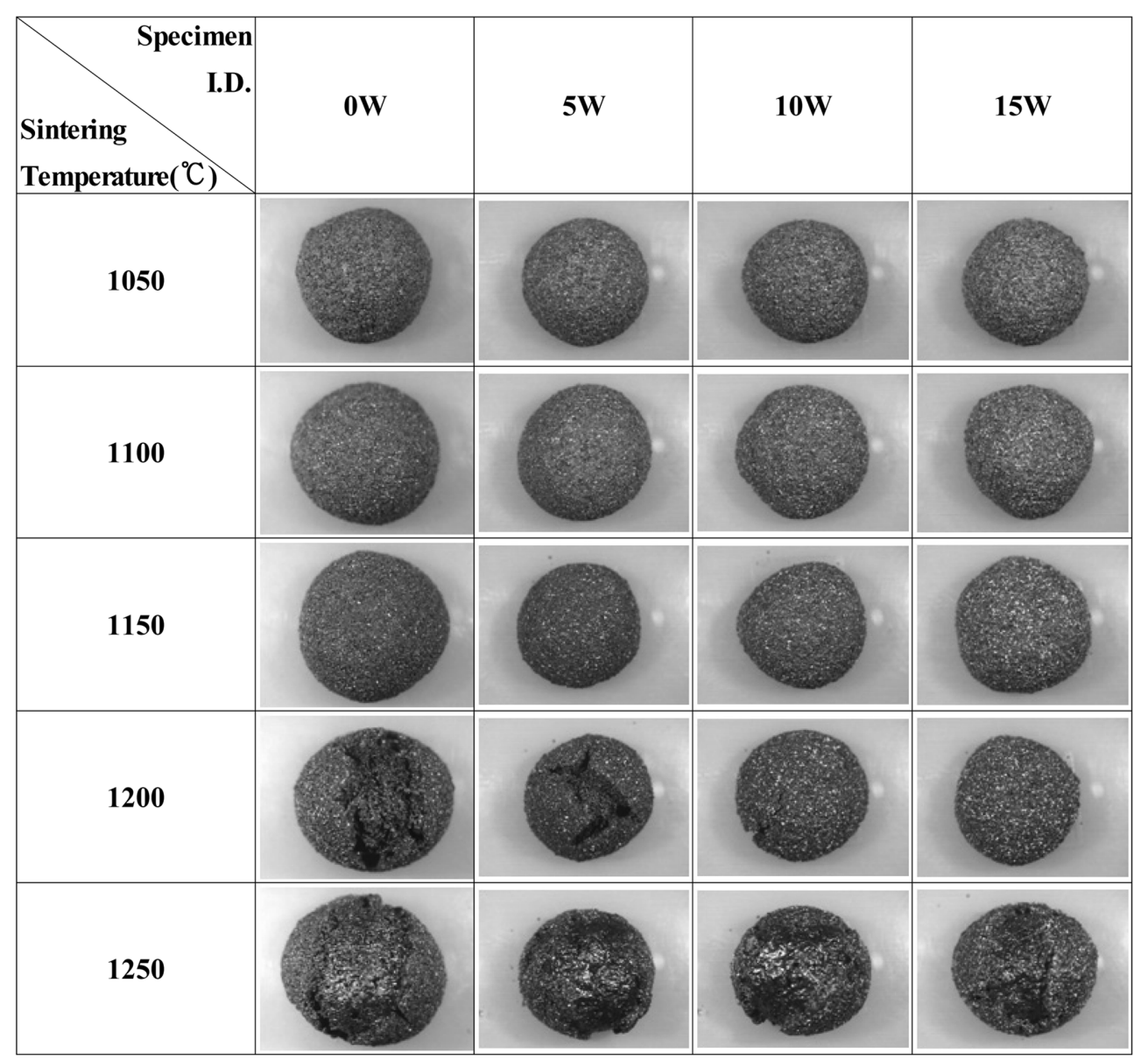

Fig. 5. Optical microscopic photographs for the external appearance of artificial aggregates sintered at $1050 \sim 1250^{\circ} \mathrm{C}$ for $10 \mathrm{~min}$ in electric furnace.

량과 함께 높아지기 때문이다(Fig. 2). 즉 소결과정에서 생성된 액상의 점도가 낮아야 시편전체를 잘 젖게 함으 로서, 시편이 점탄성 거동이 나타내면서 발포하게 하는 데, 폐유리 함량이 높은 시편은 생성된 액상의 점도가 높아 발포특성이 낮아진 것이다.

Fig. 4는 소성온도 변화에 따른 인공골재의 흡수율 변 화를 나타낸 그래프이다. 모든 시편은 소성 온도가 증가 함에 따라 흡수율이 감소하는 경향을 보였다. 또한 각 조성에 따른 흡수율은 큰 차이를 나타내지 않았고, 거의 비슷한 경향을 나타내었다. 이는 온도가 증가하면 표면 에 형성된 액상의 양도 함께 많아짐으로 생성된 액상이 표면의 개기공을 메워주어 흡수율이 낮아졌기 때문이다. 본 연구에서 제조된 인공골재들은 흡수율이 $9 \%$ 21\%의 범위를 나타내었다.

제조된 인공경량골재의 표면 미세구조사진을 Fig. 5에 나타내었다. 폐유리가 첨가되지 않은 인공골재의 표면은 소성온도가 $1050 \sim 1150^{\circ} \mathrm{C}$ 범위 내에서는 뚜렷한 변화가 나타나지 않았다. 그러나 $1200^{\circ} \mathrm{C}$ 이상의 온도로 소성된 시편은 표면에 갈라짐 현상이 나타났고, 이 양상은 소성 온도 증가와 함께 심화되었다. 이러한 표면의 갈라짐은
Fig. 4에서 보였듯이 $1200^{\circ} \mathrm{C}$ 에서 시작된 비중감소 즉 발 포현상 때문이다. 즉 시편 내부는 발포로 인하여 급속히 팽창한 반면, 껍질부분(shell)은 내부의 팽창속도를 따라 가지 못하여 표면에 균열이 발생된 것으로 보인다. 한편 폐유리 첨가량이 증가할수록 시편표면의 갈라짐 현상은 완화되었다. 예를 들어 $1200^{\circ} \mathrm{C}$ 에서 소성된 경우, 인공골 재의 표면 갈라짐 현상은 폐유리 첨가량에 따라 감소하 여, $15 \mathrm{wt} \%$ 가 첨가된 시편에서는 전혀 나타나지 않았다. $1250^{\circ} \mathrm{C}$ 에서 소성된 경우, $0 \mathrm{~W}$ 시편의 표면 갈라짐 현상 은 매우 두드러지게 나타났으며, 표면이 갈라져 드러난 부위에 액상이 형성된 것을 볼 수 있다. 또한 $1250^{\circ} \mathrm{C}$ 에 서도 폐유리 첨가량이 증가하면 표면 갈라짐 현상이 완 화되었고, 더불어 갈라진 부위의 액상 형성량도 감소된 것을 관찰할 수 있다.

인공경량골재의 절단면에 대한 미세구조사진을 Fig. 6에 나타내었다. 폐유리가 첨가되지 않은 시편 $(0 \mathrm{~W})$ 는 $1100^{\circ} \mathrm{C}$ 이하의 소성온도에서는 단면이 붉은색이었으나, $1150^{\circ} \mathrm{C}$ 이상에서 부터 내부에 검은색의 블랙코어(black core)가 형성되었다. 골재 내부에 형성되는 블랙코어의 크기 및 발생 온도는 폐유리 첨가량 증가에 따라 감소하였다. 예 


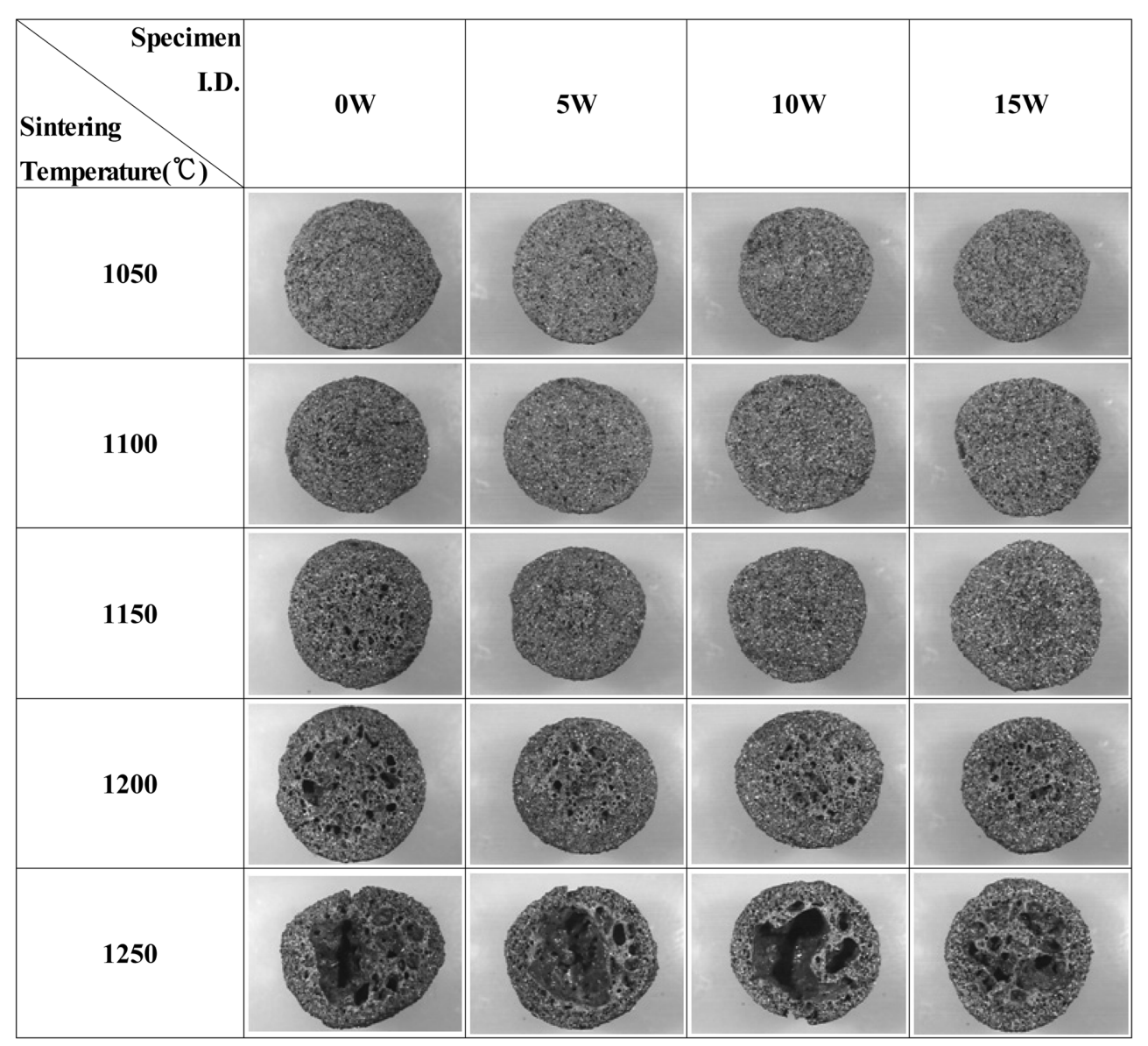

Fig. 6. Optical microscopic photographs for the cut section of artificial aggregates sintered at $1050 \sim 1250^{\circ} \mathrm{C}$ for $10 \mathrm{~min}$ in electric furnace.

를 들어, $1150^{\circ} \mathrm{C}$ 소성온도의 경우 폐유리 첨가량 증가 에 따라 블랙코어 크기가 감소하여 $15 \mathrm{~W}$ 시편에서는 블 랙코어 현상이 거의 관찰되지 않았다. 이러한 블랙코어 현상은 소결과정에서 표피에 형성된 액상에 의해 중심부 가 외부산소와 차단되어 발생한다. 즉, 내부의 $\mathrm{Fe}_{2} \mathrm{O}_{3}$ 가 $\mathrm{FeO}$ 로 환원이 되어 검은색 또는 검붉은색으로 변색되는 것이며, 이때 원료에 존재하는 미연탄소가 산화되면서 중심부의 환원분위기가 더욱 가속화 된다고 알려져 있다 $[15,16]$.

폐유리가 첨가되지 않은 골재는 $1200^{\circ} \mathrm{C}$ 에서 소성한 경 우, 내부의 기체가 포집되어 있으며, 일부 기공들은 서로 결합하여 거대기공을 형성하였다. 폐유리가 $5 \sim 10 \mathrm{wt} \%$ 첨 가된 시편에서도 $1250^{\circ} \mathrm{C}$ 에서 거대기공이 형성되었으나 $15 \mathrm{wt} \%$ 첨가된 시편에서는 거대기공 형성이 억제되었다. 이는 폐유리의 높은 융점으로 인하여 $1250^{\circ} \mathrm{C}$ 의 높은 온 도에서도 시편이 가스를 포획할 수 있는 충분한 점탄성 (visco elastic)특성을 나타내지 못했기 때문으로 생각된다.

이와 같은 결과로부터, 첨가된 폐유리는 인공골재의 발포 및 경량화 경향을 낮추었으나, $1200^{\circ} \mathrm{C}$ 이상의 소 결온도에서 발생하는 표면 갈라짐 현상을 억제하였으며
또한 $1250^{\circ} \mathrm{C}$ 이상에서 나타나는 내부의 거대기공형성을 막아주어, 균일한 기공분포를 유도하는 효과가 있음을 확인하였다.

\section{4. 결 론}

본 연구에서는 바닥재와 준설토가 $7: 3$ 으로 혼합된 배 치분말에 폐유리(폐촉매 유리질 슬래그)를 $0 \sim 15 \mathrm{wt} \%$ 첨 가한 후 직화소성법으로 인공경량골재를 제조하여 다음 과 같은 결론을 얻었다.

대부분의 시편은 $1200^{\circ} \mathrm{C}$ 에서 발포현상이 시작되었고, $1250^{\circ} \mathrm{C}$ 에서 완전 발포되어 경량화되었다. 폐유리는 용융 온도가 높고, 점도가 높아, 인공골재 내 폐유리 함유량과 함께 시편 점도가 증가하는 것으로 계산되었다. 이로 인 해 발포현상이 완전히 일어난 $1250^{\circ} \mathrm{C}$ 에서 소결된 경우, 폐유리 함량과 함께 비중값이 증가하여, 발포경향이 폐 유리 함량에 반비례하였다. 한편 모든 시편은 소성 온도 가 증가함에 따라 흡수율이 감소하는 경향을 보였다.

소결온도 $1200^{\circ} \mathrm{C}$ 에서 시작된 발포현상으로 인해 시편 
표면에 균열이 나타났으며, $1250^{\circ} \mathrm{C}$ 에서는 많은 량의 액 상이 표면에 형성되었으나, 이러한 현상은 폐유리를 첨 가함으로서 제어가 가능하였다. 폐유리가 첨가되지 않은 골재는 $1200^{\circ} \mathrm{C}$ 에서 소성한 경우, 내부에 기체가 포집되 면서 거대기공을 형성하였으나, 폐유리를 첨가하면 시편 내 거대기공 형성이 억제되면서 기공분포를 균일화시키 는 효과를 보였다.

본 연구를 통하여 폐유리 첨가량을 $0 \sim 15 \mathrm{wt} \%$ 범위로 첨가함으로서 인공골재의 표면균일현상을 억제할 수 있 었고, 균일한 기공분포를 얻을 수 있음을 확인하였다. 제 조된 인공골재는 폐유리의 첨가량에 따라 비중은 1.1 1.5 , 흡수율은 8 22\% 범위의 값을 나타내어 인공경량골 재의 $\mathrm{KS}$ 기준을 만족함으로서 향후 비구조용 건축자재 로서 적용이 가능할 것으로 판단된다.

\section{감사의 글}

본 연구는 2011학년도 경기대학교 학술연구비(일반연 구과제) 지원에 의하여 수행되었음.

\section{참 고 문 헌}

[ 1 ] B. Raju, J.Y. Lee and H.K. Park, "Process for the separation and recovery of palladium and platinum from spent automobile catalyst leach liquor using LIX 84I and Alamine 336", Journal of Hazardous Materials 180[1-3] (2010) 253.

[2] J.C. Lee: Recycling white paper, Resource Recycling R\&D Center, translated by Korean, Chungmungak Publication, Paju (2004).

[3] K.D. Kim and S.G. Kang, "Manufacturing artificial lightweight aggregates using coal bottom ash and clay", J. Kor. Cryst. Growth and Cryst. Tech. 17[6] (2007) 277.
[4] K.D. Kim, J.H. Kim, Y.T. Kim, K.G. Lee and S.G. Kang, "Production of lightweight aggregates using power plant reclaimed ash", Journal of the Korean Ceramic Society 47[6] (2010) 583.

[5] S.U. Shin, S. Kumar, T.U. Jung and B.W. Shin, 'The strength and characteristic of PCC bottom ash", J. Kor. Geo-Environ Soc. 8(2) (2002) 57.

[6] I. Kula, A. Olgun, V. Sevinc and Y. Erdogan, "An investigation on the use of tinal ore waste, fly ash, and coal bottom ash as Portland cement replacement materials", Cement and Concrete Res. 32 (2002) 227.

[ 7 ] D.U. Lee and Y.S. Kim, "A study on the strength properties of concrete containing bottom ash as a part of fine aggregate", J. Architectural Institute Kor. 22(6) (2006) 79.

[ 8 ] S.J. Kim, "Treatment, disposal, and reuse of contaminated dredged sediment in the ocean", Journal of the Korean Society of Civil Engineers, 55[4] (2007) 66.

[9] K.I. Lee, "Recycling of waste as a resource-circulating society building", Geoenvironmental Engineering 2[1] (2001) 55.

[10] B.H. Bae, "Comparison of the country with Busan city in wastes generation and disposal", Journal Korean Society of Environmental Administration 8[4] (2002) 409.

[11] C.M. Riley, "Relation of chemical properties to the bloating of clay", J. Am. Ceram. Soc. 34[4] (1951) 121.

[12] H. Scholze, "Glass Engineering", translated in Korean, Chungmungak (1995).

[13] T. Lakatos, L.G. Johansson and B. Simmingskod, "Viscosity temperature relation in the glass system $\mathrm{SiO}_{2}$ $\mathrm{Al}_{2} \mathrm{O}_{3}-\mathrm{Na}_{2} \mathrm{O}-\mathrm{K}_{2} \mathrm{O}-\mathrm{CaO}-\mathrm{MgO}$ in the composition range of technical glasses", Glass Technol. 13 (1972) 88.

[14] Y.M. Chiang, D. Mirnie III and W.D. Kingery, Physical Ceramics, John Wiley \& Sons., Inc., New York (1997) p. 90.

[15] J.Y. Park, Y.T. Kim, K.G. Lee, S.G. Kang and J.H. Kim, "The mechanism of black core formation", J. Kor. Cryst. Growth and Cryst. Tech. 15[5] (2005) 208.

[16] J.C. Hostetter and H.S. Roberts, "Notes on the dissociation of ferric oxide dissolved in glass and its relation to the color of iron-bearing glasses", J. Am. Ceram. Soc. 4[11] (1921) 927. 